Original Research Paper

\title{
Konservasi Sumberdaya Alam Berwawasan Kearifan Lokal Melalui Sosialisasi Peningkatan Kesadaran Lingkungan Pada Masyarakat Desa Bagik Payung Timur, Lombok Timur
}

\author{
Agil Al Idrus ${ }^{1 *}$, Liwa Ilhamdi ${ }^{2}$, I Gde Mertha ${ }^{3}$, LL. Abd. Muhyi Abidin ${ }^{4}$ Lale Yaqutunnafis $^{5}$ \\ ${ }^{1,2,3}$ Program Studi Pendidikan Biologi, Fakultas Keguruan dan Ilmu Pendidikan Universitas Mataram, Indonesia \\ ${ }^{4}$ Program Studi Bahasa Inggris, Fakultas Keguruan dan Ilmu Pendidikan, Universitas Nahdlatul Wathan Mataram, \\ Indonesia \\ ${ }^{5}$ Program Studi Pendidikan Ekonomi, Fakultas Keguruan dan Ilmu Pendidikan, Universitas Nahdlatul Wathan \\ Mataram, Indonesia
}

https://doi.org/10.29303/jpmpi.v3i2.996

Sitasi: Idrus, A. A., Ilhamdi, L., Mertha, I. G., Abidin, LL. A. M \& Yaquttunafis, L (2021). Konservasi Sumberdaya Alam Berwawasan Kearifan Lokal Melalui Sosialisasi Peningkatan Kesadaran Lingkungan Pada Masyarakat Desa Bagik Payung Timur, Lombok Timur. Jurnal Pengabdian Magister Pendidikan IPA, 4(3)

Article history

Received: 5 September 2021

Revised: 27 September 2021

Accepted: 29 September 2021

*Corresponding Author: Agil Al Idrus, Program Studi Pendidikan Biologi Jurusan Fakultas Keguruan dan Ilmu Pendidikan Universitas Mataram, Indonesia;

Email: agil.alidrus2004@yahoo.com
Abstrak: Potensi sumberdaya alam berupa lahan tambang pasir yang ada di Desa Bagik Payung Timur dapat meningkatkan kualitas hidup secara ekonomi bagi masyarakat sekitar. Namun, kegiatan penambangan pasir yang dilakukan oleh masyarakat seringkali tidak mempertimbangkan faktor pembatas ekologi sehingga cenderung eksploitatif dan berpotensi menimbulkan dampak lingkungan yang tidak sehat bagi masyarakat dan lingkugan sekitar. Kurangnya kesadaran masyarakat dalam menjaga dan mengelola sumberdaya alam khususnya lahan tambang pasir menjadi masalah yang harus dituntaskan dengan pendekatan yang humanis dan mengedepankan kearifan lokal. Tujuan pengabdian masyarakat adalah untuk mensosialisasikan konservasi sumberdaya alam berwawasan kearifan lokal di Desa Bagik Payung Timur, Kecamatan Suralaga Lombok Timur. Metode yang digunakan adalah pendampingan berupa sosialisasi, diskusi, Tanya jawab. Hasil Pengabdian menunjukkan bahwa semua peserta yang hadir sangat antusias mengikuti kegiatan pengabdian yaitu sosialisasi, diskusi dan Tanya jawab tentang konservasi berwawasan kearifan lokal pada masyarakat Desa Bagik Payung Timur. Serangkaian kegiatan pengabdian pada masyarakat ini telah berlangsung dengan kesimpulan sebagai berikut: semua peserta yang terdiri dari warga masyarakat yang ada di Desa Bagik Payung sangat antusias mengikuti seluruh rangkaian kegiatan dengan memberikan respon yang positif selama kegiatan pengabdian berlangsung. Tim Pengabdian memaparkan dan memberikan sosialisasi manfaat sumberdaya alam yang dikelola dengan proporsional berwawasan kearifan lokal dan kerusakan lingkungan akibat eksploitasi sumberdaya yang berlebihan. Peserta aktif menanyakan hal-hal yang belum jelas dari materi sosialisasi. Pada akhir kegiatan pengabdian masyarakat mempunyai pengetahuan terkait materi sosialiasai baik tentang manfaat sumberdaya alam yang dikonservasi dengan baik sehingga masyarakat dapat menjaga dan melestarikan lingkungan sekitar.

Keywords: Konservasi, Tambang Pasir, Kearifan Lokal, Bagik Payung Timur 


\section{Pendahuluan}

Tonservasi sumberdaya alam merupakan salah Nsatu hal yang sangat substansial karena kelestarian dan manfaat sumberdaya alam bagi lingkngan dan masyarakat menjadi harapan yang harus direalisasikan secara optimal, akan tetapi kegiatan eksploitasi sumberdaya alam masih banyak dilakukan oleh masyarakat tanpa memperhatikan dampak negatif yang akan ditimbulkan. Hal ini disebabkan karena masih kurangnya kesadaran dan wawasan terkait konservasi dan pengelolaan sumberdaya alam.

Kegiatan konservasi sumberdaya alam harus memperhatikan aspek-aspek biofisik, aspek sosial, ekonomi dan budaya masyarakat lokal. Karena konservasi yang dilakukan secara komperhensif dapat memberikan hasil yang terbaik dalam kurun waktu yang cukup panjang (Suparmini et al. 2013). Kegiatan konservasi akan berjalan dengan baik apabila semua pihak bekerjasama dan saling mendukung satu sama lainnya. Khususnya keterlibatan masyarakat setempat yang ada di kawasan konservasi. Selain itu pemerintah desa memiliki peran yang sangat penting dalam melakukan pemerataan dan menata kawasan konservasi yang ada di lingkungan masyarat.

Desa Bagik Payung Timur merupakan salah satu desa yang ada di Kecamatan Suralaga Kabupaten Lombok Timur. Desa Bagik Payung Timur memiliki luas wilayah yaitu sekitar $250 \mathrm{Ha}$ terbagi dalam 4 (Empat) wilayah kekadusan yaitu Dusun Praida, Dusun Lendang Bagik, Dusun keroya, Dusun Karang Baru (BPS Lombok Timur, 2020). Ada tiga jenis mata pencaharian masyarakat Desa Bagik Payung Selatan diantaranya penambang, pekebun dan petani. Kondisi Topografi wilayah yang ada di Desa Bagik Payung Timur sebagaian besar berupa lahan pertambangan pasir, sehingga masyarakat yang ada di Desa Bagik Payung Timur banyak bermata pencaharian sebagai penambang dan buruh tambang. Selain potensi tambang pasir, lahan perkebunan kelapa juga menjadi ciri khas Desa Bagik Payung Timur karena dapat menghasilkan komoditas kelapa sampai dikirim ke luar daerah. Sumberdaya tersebut perlu harus dikelola dan dijaga dengan sebaik-baiknya guna meningkatkan taraf ekonomi masyarakat sekitar.

Konservasi sumberdaya alam berwawasan kearifan lokal merupakan salah satu pendekatan yang dapat diaplikasikan secara langsung dengan memperhatikan budaya, keyakinan dan etika yang ada di tengah-tengah masyarakat. Sehingga dapat menuntun perilaku manusia dalam kehidupan di dalam komunitas ekologis (Keraf, 2015). Partisipasi masyarakat yang tinggi dalam pengelolaan sumberdaya alam akan memberikan dampak yang cukup signifikan pada aspek ekonomi dan ekologi. Aspek ekonomi berimplikasi pada peningkatan pendapatan dan taraf hidup masyarakat, serta aspek ekologi dimana partisipasi masyarakat tersebut akan berkontribusi dalam kegiatan menjaga kelestarian sumberdaya alam dan lingkungan sekitaranya (Nasikh (2009). Oleh karena itu, kesadaran masyarakat dan partisipasi masyarakat dalam mengupayakan konservasi sumberdaya alam khususnya lahan penambangan pasir yang ada di Desa Bagik Payung Timur sangat menentukan kelestarian lingkungan untuk masa-masa yang akan datang.

\section{Metode}

Metode pelaksanaan kegiatan pengabdian masyarakat ini difokuskan pada Langkah-langkah konservasi berwawasan kearifan lokal dan penyelesaian masalah yang sedang dihadapi oleh masyarakat dalam memahami peran dan fungsi sumberdaya alam khususnya area penambangan pasir. Permasalahan yang dialami masyarakat dapat diatasi dengan mensosialisasikan peran dan fungsi sumberdaya alam yang ada di Desa Bagik Payung Timur. Kegiatan pengabdian ini dilaksanakan pada tanggal 25 September 2021 yang bertempat di Desa Bagik Payung Timur, Kecamatan Suralaga, Kabupaten Lombok Timur. Sosialisasi peran dan fungsi sumberdaya alam tersebut dilakukan dalam bentuk sosialisasi, diskusi dan Tanya jawab. Sosialisasi dilakukan dalam bentuk penyampaian materi (teori/konsep) dan Langkah-langkah konservasi. Peserta sosialisasi akan direkrut yaitu kelompok penambang dan pekebun dan masyarakat setempat. Penyampaian materi dilakukan dalam bentuk klasikal. Materi yang akan disampaikan terdiri dari (1) pentingnya melakukan konservasi untuk kelestarian lingkungan, dan (2) menyampaikan langkah-langkah konservasi lingkungan. 


\section{Hasil dan Pembahasan}

Pengetahuan masyarakat terhadap konservasi lingkungan yang ada di Desa Bagik Payung Timur sangat perlu ditingkatkan agar masyarakat dapat mengelola sumberdaya alam yang ada di desa tersebut dengan bijak dan humanis. Kegitan sosialisasi dalam kegiatan pengabdian yang telah dilaksanakan merupakan salah satu upaya dalam mengingkatkan kesadaran masyarakat sekitar. Karena sumberdaya berupa lahan tambang pasir yang ada di desa tersebut perlu dikelola dengan tidak melakukan kegiatan tambang secara berlebihan tanpa memperhatikan faktor pembatas ekologi sehinga menimbulkan dampak lingkunga yang serius bagi masyarakat dan lingkungan sekitar. Oleh karena itu dalam kegiatan sosialisasi ini, masyarakat dibekali dengan materi yang berkaitan dengan perlunya dilakukan konservasi sejak ini dan hal-hal yang akan ditimbulkan akibat kegiatan penambangan pasir yang tidak terkendali serta langkah-langkah yang dapat dilakukan oleh masyarakat dalam melakukan konservasi dengan menggunakan pendekatan kearifan lokal.

Selama kegiatan diskusi, pemateri menekankan bahwa aktivitas penambangan pasir harus dilakukan dengan memperhatikan kelestarian lingkungan. Artinya masyarakat harus mempertimbangkan daya dukung sumberdaya tambang dan faktor pembatasnya agar tidak terjadi eksploitasi yang berlebihan. Selain itu, kesadaran masyarakat untuk mengelola sumberdaya lahan dengan bijak harus dibudayakan agar sumberdaya lahan tambang pasir tidak terdegradasi akibat kegiatan pertambangan yang tidak ramah lingkungan.

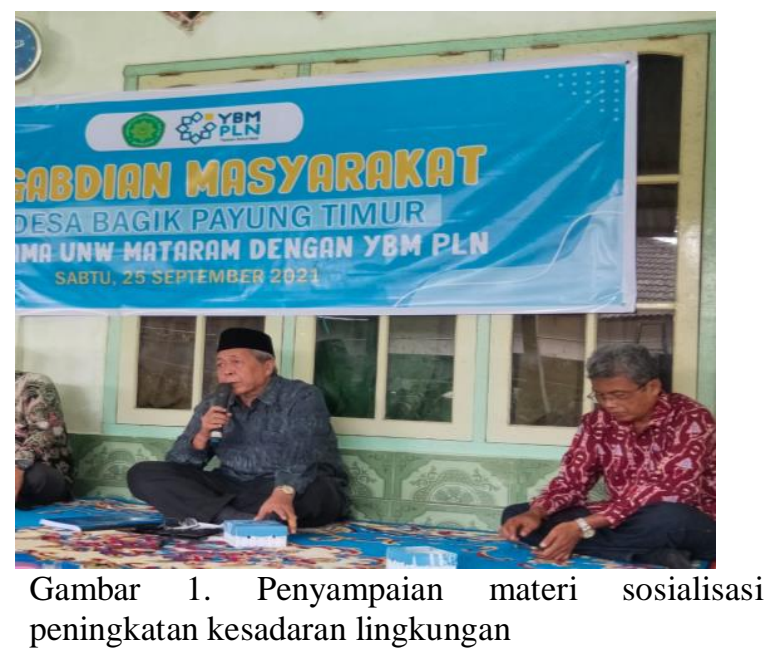

\section{a. Manfaat Konservasi Sumberdaya Alam}

Konservasi sumberdaya alam merupakan kegiatan yang dilakukan untuk menjaga kelestarian sumberdaya alam dengan memperhatikan faktorfaktor yang berpotensi merusak sumberdaya agar dapat dikendalikan. Kegiatan konservasi memerluakan usaha dan tindakan yang jelas dan terukur sehingga terjadi siklus yang saling meguntungkan antara masyarakat yang mengambil manfaat dari sumberdaya alam dengan lingkungan.

Manfaat kegiatan konservasi yang dilakukan oleh masyarakat setempat tidak hanya berdampak positif terhadap kelangsungan ekosistem dan sumberdaya alam melainkan akan memberikan keuntungan secara ekonomi, sosial dan budaya. Secara ekologis, konservasi yang dilakukan oleh masyarakat dapat menjaga kualitas lingkungan serta siklus ekologi dapat bekerja dengan optimal. Manfaat secara ekonomi berbentuk ketersediaan sumberdaya alam yang dapat dimafaatkan oleh masyarakat dalam jangka waktu yang relatif panjang.

\section{b. Kerusakan Lingkungan Akibat Eksploitasi Sumberdaya Alam}

Kegiatan pertambangan pasir oleh masyarakat yang ada di Desa Bagik Payung Timur menjadi aktivitas yang sangat digemari karena dapat memberikan keuntungan ekonomi secara signifikan. Namun masyarakat perlu menyadari bahwa sumberdaya mempunyai ambang batas maksimum, apabila kegiatan pertambangan dilakukan secara berlebihan dan tidak terkendali akan menimbulkan kerusakan yang serius seperti terjadinya longsor, ketersediaan air berkurang, perubahan struktur tanah dan kapasitas dan penyerapan air tanah menurun. Selain tu Kegiatan penambangan pasir yang menggunakan alat berat yang berfungsi untuk mengeruk material berpotensi menimbulkan permasalahan ekologis dan sosial bagi lingkungan sekitar (Yudhistira et al. 2011).

Kerusakan fisik yang diakibatkan oleh aktivitas pertambangan akan semakin meningkat jika tidak terkendali dengan proporsional. Kerusakan fisik yang berpotensi terjadi dintaranya erosi di daerah penambangan pasir dan juga 
didaerah sekitarnya semakin meningkat. Kemudian adanya tebing-tebing bukit yang rawan longsor. sumber mata air berkurang. Serta rusaknya jalan akibat tingginya intensitas kendaraan tambang pasir yang berlalu lintas serta polusi udara semakin meningkat.

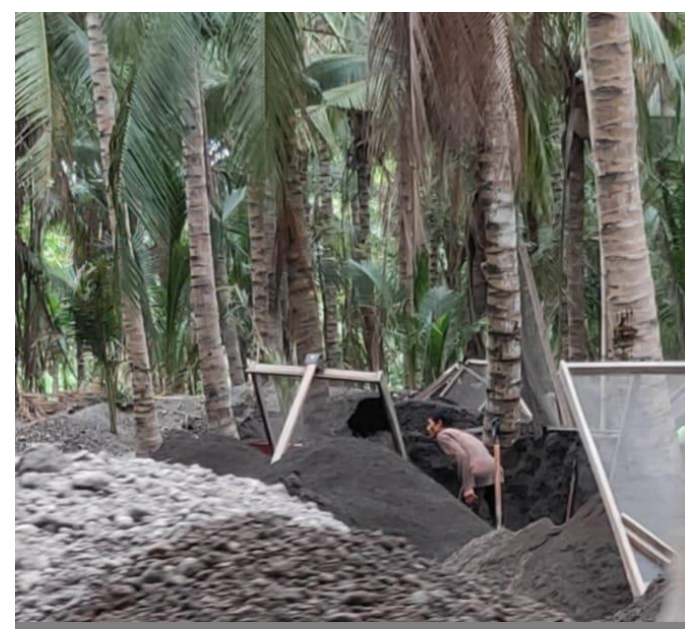

Gambar 2. Aktivitas penambangan pasir oleh masyarakat di Desa Bagik Payung Timur

\section{c. Upaya Konservasi Sumberdaya Alam Berwawasan Kearifan Lokal}

Masyarakat yang tinggal di sekitar daerah tambang pasir memiliki peran yang sangat penting dalam melakukan konservasi lahan tambang miliknya agar tidak terjadi kerusakan yang dapat membahayakan masyarakat dan lingkungan sekitar. Kehadiran masyarakat dalam pengelolaan sumberdaya alam khususnya lahan tambang pasir sangat penting dalam menjaga kelestarian lingkungan. Namun, dalam membudayakan masyarakat diperlukan ketelatenan dan juga kesabaran dalam membina, karena masyarakat tidak serta-merta dapat berubah secara drastis begitu saja. Proses yang dilakukan sangatlah panjang, serta perlu pendampingan yang terus menerus supaya masyarakat mempunyai pemahaman sesuatu dalam pengalamannya sehingga masyarakat dapat membudayakan dirinya dalam memanfaatkan suatu potensi sumberdaya alam secara bijaksana (Rookes dan Wilson, 2000).
Tradisi dan budaya menjaga kelestarian lingkungan agar tetap berfungsi dan memberikan manfaat khususnya bagi masyarakat dan ekosistem sekitar perlu dilestarikan. Karena terwujudnya etika dan budaya masyarakat yang menghormati nilai-nilai kelestarian lingkungan sebagai kebutuhan dan kepentingan yang mendasar bagi masyarakat dalam kegiatan melestarikan sumberdaya beruapa lahan yang dimanfaatkan oleh masyarakat setempat (Erlina et al. 2018).

Konservasi berbasis kearifan lokal merupakan suatu metode konservasi yang mengedepankan tradisi, budaya dan kebiasaan masyarakat setempat yang dapat dilakukan oleh masyarakat karena tidak bertentangan dengan asasasas yang berlaku di tengah masyarakat. Pendekatan konservasi yang berbasis kearifan lokal cenderung mudah dipahami dan diikuti oleh masyarakat karena masyarakat meyakini bahwa lingkungan harus dijaga dengan sebaik-baiknya agar dapat diwariskan anak cucunya pada masamasa yang akan datang. Konservasi berbasis kearifan lokal memberikan dampak yang baik terhadap aspek sosial, ekonomi dan ekologi (Lerebulan et al. 2019).

Kegiatan sosialisasi terkait konservasi sumberdaya alam berwawasan kearifan lokal diakhiri dengan sesi tanya jawab kemudian dilanjutkan dengan pembagian paket sembako oleh tim pengabdian kepada peserta yang hadir dalam acara sosialisasi tersebut. Kegiatan pengabdian ini disambut baik oleh masyarakat terlihat dengan semangat dan antusias peserta dalam sesi FGD dan tanya jawab selama kegiatan sosialisasi berlangsung.

Peserta yang menghadiri kegiatan sosialisasi sangat antusias. Dalam sesi tanya jawab salah seorang peserta menanyakan kepada narasumber terkait dengan potensi tambang pasir yang semakin berkurangan apabila masyarakat terus-menerut melakukan aktivitas pertambangan. Kemudian narasumber menjelaskan agar masyarakat atau penambang harus memperhatikan daya dukung lahan tambang agar tidak dieksploitasi secara berlebihan. Dalam hal ini masyarakat harus memperhitungkan intensitas pertambangan agar tidak melebihi ambang batas. Selain itu, masyarakat 
harus meningkatkan keterampilannya untuk memanfaatkan sumberdaya lainnya seperti pemanfaatan sumberdaya kelapa dengan menggunakan inovasi baru dengan sentuhan teknologi agar memiliki nilai tambah. Kegiatan diskusi dan tanya jawab berjalan dengan lancar hingga akhir acara. Peserta yang hadir sangat senang karena mendapatkan ilmu terkait dengan konservasi lingkungan yang selama ini belum diperoleh karena minimnya sosialisasi dan pelatihan yang diikuti. Sehingga kegiatan pengabdian yang dilaksanakan oleh tim pengabdian masyarakat mendapatkan respon yang sangat positif dari masyarakat Desa Bagik Payung Timur.

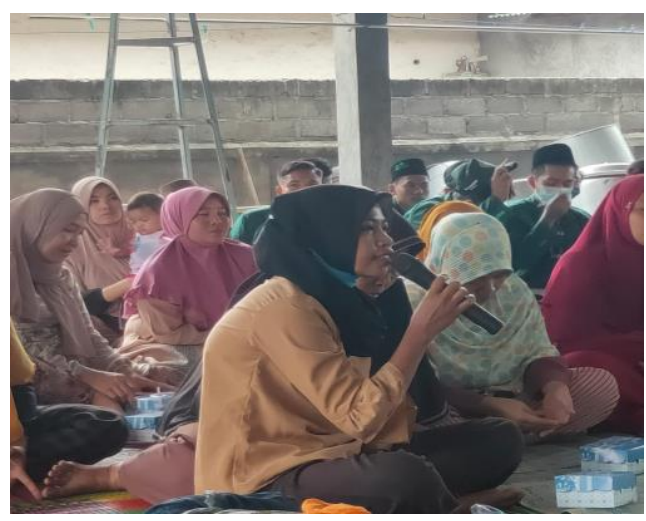

Gambar 3. Sesi tanya jawab dengan narasumber

Kegiatan pengabdian akhiri dengan pemberian bantuan sembako kepada masyarakat yang menghadiri kegiatan sosialisasi. Paket bantuan sembako merupakan bantuan yang diperoleh dari hasil kerjasama lembaga Universitas Nahdlatul Wathan Mataram dengan YBM PLN wilayah Nusa Tenggara Barat sebagai salah satu upaya peningkatan gizi masyarakat yang terkena dampak pandemi Covid-19. Pemberian bantuan sembako tersebut disambut baik oleh masyarakat karena banyak masyarakat yang ada di Desa Bagik Payung Timur terkena dampak Covid-19.

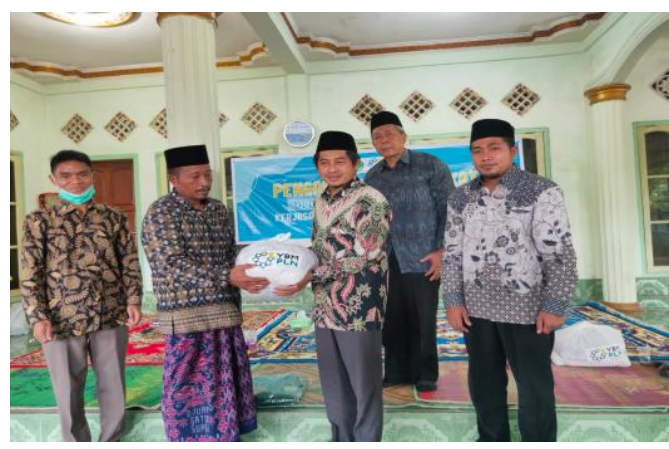

Gambar 4 . Pemberian bantuan oleh Tim pengabdian kepada perwakilan desa
Kegiatan sosialisasi terkait konservasi sumberdaya alam berjalan dengan lancar hingga akhir acara. Masyarakat diharapkan dapat mengaplikasikan ilmu yang telah diperoleh dari kegiatan sosialisasi agar sumberdaya yang ada di Desa Bagik Payung Timur terkelola dengan baik dan memberikan manfaat bagi masyarakat dan lingkungan sekitar.

\section{Kesimpulan}

Serangkaian kegiatan pengabdian pada masyarakat ini telah berlangsung dapat diambil kesimpulan sebagai berikut: semua peserta yang terdiri dari warga masyarakat yang ada di Desa Lombok Timur sangat antusias mengikuti seluruh rangkaian kegiatan dengan memberikan respon yang positif selama kegiatan pengabdian berlangsung. Tim Pengabdian memaparkan dan memberikan sosialisasi manfaat sumberdaya alam yang dikelola dengan proporsional berwawasan kearifan lokal dan kerusakan lingkungan akibat eksploitasi sumberdaya yang berlebihan. Peserta aktif menanyakan hal-hal yang belum jelas dari materi sosialisasi. Pada akhir kegiatan pengabdian masyarakat mempunyai pengetahuan terkait materi sosialiasai baik tentang manfaat sumberdaya alam yang dikonservasi dengan baik sehingga masyarakat dapat menjaga dan melestarikan lingkungan sekitar.

\section{Ucapan Terima Kasih}

Tim pengabdian pada masyarakat menyampaikan ucapan terima kasih kepada Lembaga Penelitian dan Pengabidan kepada Masyarakat Universitas Nahdlatul Wathan Mataram yang telah memberikan kesempatan sehingga kegiatan pengabdian pada masyarakat ini terlaksana dengan lancar. Kemudian terimakasih juga kepada Yayasan Baitul Maal PLN Wilayah Nusa Tenggara Barat yang telah memberikan bantuan materiil sehingga kegiatan pengabdian ini berjalan dengan baik.

\section{Daftar Pustaka}

BPS Lombok Timur. 2020. Kecamatan Suralaga Dalam Angka. BPS Kabupaten Lombok Timur/BPS- 
Statistics of Lombok Timur Regency: UD Maharani.

Erlina, B., Hartono, B., Anggalana, A., dan Safitri, M. 2018. Optimalisasi Nilai Kearifan Lokal Rembug Pekon dalam Pengelolaan Taman Hutan Raya (TAHURA) Wan Abdurahman Propinsi Lampung sebagai Kawasan Hutan Konservasi Berbasis Masyarakat. Keadilan Progresif, 9(2): 100-112.

Keraf A. Sonny. 2005 Etika Lingkungan. Jakarta: Penerbit Buku Kompas.

Lerebulan, M., Girsang, W., \& Siwalette, J. D. 2019. Pengelolaan Sumberdaya Alam Berbasis Kearifan Lokal (Studi Kasus Sasi Di Desa Watmuri Kepulauan Tanimbar). AGRILAN: Jurnal Agribisnis Kepulauan, 6(3): 284-298.

Nasikh. 2009. Partisipasi Masyarakat pada Pengelolaan Hutan di Kawasan Gerakan Rehabilitasi Hutan dan Lahan (Gerhan) Pasuruan Jawa Timur. Jurnal Masyarakat Kebudayaan dan Politik, 22(2):35-45.

Rookes, P., and Wilson, J. 2000. Perception: theory, development, and organization. London: Routledge.

Suparmini, S., Setyawati, S., \& Sumunar, D. R. S. 2013. Pelestarian lingkungan masyarakat Baduy berbasis kearifan lokal. Jurnal Penelitian Humaniora, 18(1): 8-22.

Yudhistira, Y., Hidayat, W. K., \& Hadiyarto, A. (2011). Kajian dampak kerusakan lingkungan akibat kegiatan penambangan pasir di Desa Keningar daerah kawasan Gunung Merapi. Jurnal Ilmu Lingkungan, 9(2): 76-84. 